\title{
Cadaveric Study of Accessory/Aberrant Left Hepatic Artery From Left Gastric Artery - Embryological Basis \& Its Clinical Significance
}

Research Article

Priyanka $\mathrm{K}^{1}$, Amar Singh L $\mathrm{2}^{*}$, Archana $\mathrm{BJ}^{2}$, Asha $\mathrm{KR}^{3}$

${ }^{1}$ Tutor, Sri Siddhartha Institute of Medical Sciences and Research Center, Karnataka, India.

${ }^{2}$ Associate Professor, Department of Anatomy, Sri Siddhartha Institute of Medical Sciences and Research Center, Karnataka, India.

${ }^{3}$ Proffessor \& HOD, Department of Anatomy, Sri Siddhartha Institute of Medical Sciences and Research Center, Karnataka, India.

\section{Abstract}

\begin{abstract}
Aim: The present study aims at contributing to the existing information related to the incidence of origin of aberrant left hepatic artery from left gastric artery and its clinical significance. The information of branching patterns of arteries, their embryological basis and variations is important in various surgical and radiological procedures.

Material and Methods: Fifty (50) embalmed adult human cadavers of both sexes were dissected for the study in the department of anatomy in Sri Siddhartha Medical College and other medical colleges in and around Bangalore.

Results: Out of the 50 specimens, four specimens (8\%) showed the presence of aberrant left hepatic artery arising from the left gastric artery and it was accessory type in all the four cases.

Conclusions: A good knowledge about the embryological basis \&variations in the branching pattern of left gastric artery is essential to reduce the complications and increase the success rate in surgical and interventional procedures in hepatobiliary region.
\end{abstract}

Keywords: Left Gastric Artery; Aberrant Left Hepatic Artery; Accessory Left Hepatic Artery; Embryological Basis; Clinicalsignificance.

\section{Introduction}

The Coeliac trunk is the first unpaired vessel of abdominal aorta, normally trifurcates into left gastric, splenic and common hepatic arteries. The common hepatic artery after its origin from Coeliac trunk divides into right and left branches to the respective lobes of the liver [1-3]. Variations in the hepatic arterial anatomy are common and knowledge about them plays a crucial role during hepatobiliary surgeries $[4,5]$. The hepatic artery considered as aberrant is of two types, namely, 'accessory' and 'replaced'. The aberrant is accessory hepatic when it is seen as additional to the one which is normally (usually) present. The aberrant is replacing hepatic when it is seen as substitute to the normal (usual) hepatic artery which is absent [6]. In about $12 \%$ of individuals it has been shown that the aberrant hepatic arterial variation as the right hepatic artery arising from superior mesentery artery and in about $25 \%$ of cases it has been shown that the left hepatic artery or accessory left hepatic artery to be arising from left gastric artery
[7]. It has also been reported earlier about the incidence of accessory left hepatic artery to be arising from left gastric artery in about $6-8 \%$ of the specimens and at the same time the incidence of replaced left hepatic artery was also arising from left gastric artery itselfin about $8-10 \%$ of the specimens [8-10]. The aim of the present study is to observe the incidence of origin of aberrant left hepatic artery from the left gastric artery and to note its embryological basis \& clinical significance.

\section{Materials and Methods}

Fifty (50) embalmed adult human cadavers of both the sexes were studied. The specimens were obtained from the Department of Anatomy, Sri Siddhartha Medical College, Bangalore. Abdomen was opened and dissected according to the Cunningham's manual. The Coeliac trunk and its branches were located and cleaned. The common and hepatic artery proper and its branches going towards porta hepatics were also located and cleaned. The left

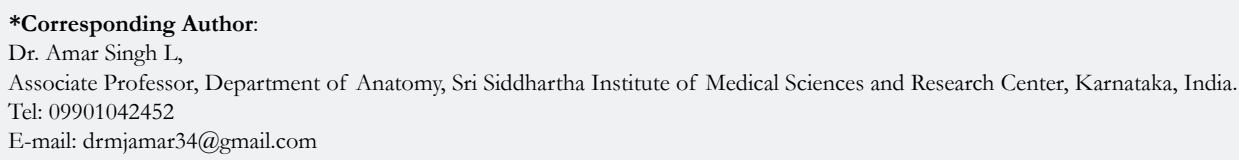

Copyright: Amar Singh L ${ }^{\circ}$ 2020. This is an open-access article distributed under the terms of the Creative Commons Attribution License, which permits unrestricted use, distribution and reproduction in any medium, provided the original author and source are credited. 
gastric artery was identified and traced anticipating aberrant left hepatic artery. The observations noted were analyzed and compared with the previous studies.

\section{Results}

Study was conducted on 50 specimens, out of which four specimens $(8 \%)$ showed the presence of aberrant left hepatic artery arising from left gastric artery. It was also observed that the aberrant left hepatic artery was accessory to the left hepatic artery (Figure $1 \& 2$ ). After its origin from the left gastric artery, the aberrant accessory left hepatic artery ascended upwards staying close to the lower end of esophagus within the layers of lesser omentum, later it entered the liver by passing through the porta hepatic. During its course it gave 3-4 branches to the lower end of esophagus. Rest of the 46 specimens showed the normal hepatic arterial pattern.

\section{Discussion}

The arterial supply of liver shows anatomical variations and has been reported in about $25-50 \%$ population $[11,12,3,5]$. The present study shows aberrant hepatic artery in four $(8 \%)$ case. Studies have shown that the incidence of aberrant left hepatic artery arising from left gastric artery varies from $6.1-21 \%$ of cases [13-19, 5, 8]. Table 1.

Figure 1. Accessory left hepatic artery arising from left gastric artery.

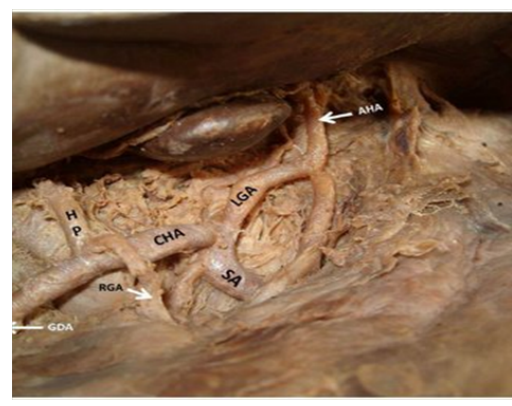

Legends:

CHA- Common hepatic artery; SA- Splenic artery; LGA-Left gastric artery

AHA- Accessory hepatic artery; HP- Hepatic artery proper; RGA- Right gastric artery; GDA- Gastro duodenal artery

Figure 2. Accessory left hepatic artery arising from left gastric artery.

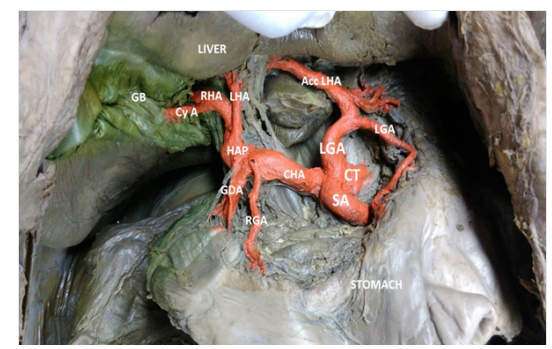

Legends:

Acc LHA- Accessory left hepatic artery; CT- Coeliac trunk

CHA- Common hepatic artery; SA- Splenic artery; LGA- Left gastric artery

RGA- Right gastric artery; GDA- Gastro duodenal artery

HAP- Hepatic artery proper; LHA- Left hepatic artery

RHA- Right hepatic artery; Cy A- Cystic artery; GB- Gall bladder

Table 1. Showing the incidence of aberrant left hepatic artery arising from left gastric artery.

\begin{tabular}{|c|c|c|c|c|}
\hline Author & $\begin{array}{c}\text { Number of } \\
\text { specimens }\end{array}$ & $\begin{array}{c}\text { Aberrant left } \\
\text { hepatic artery }\end{array}$ & $\begin{array}{c}\text { Replaced left } \\
\text { hepatic artery }\end{array}$ & $\begin{array}{c}\text { Accessory left } \\
\text { hepatic artery }\end{array}$ \\
\hline Andujar & 1081 & $13.60 \%$ & $9.70 \%$ & $3.90 \%$ \\
\hline Covey & 600 & $15.20 \%$ & $4.50 \%$ & $10.70 \%$ \\
\hline Iezzi & 524 & $6.10 \%$ & $5.90 \%$ & $0.20 \%$ \\
\hline Winston & 371 & $12 \%$ & $8 \%$ & $4 \%$ \\
\hline Rawat & 125 & $12.80 \%$ & $4 \%$ & $8.80 \%$ \\
\hline Urugel & 100 & $21 \%$ & $11 \%$ & $10 \%$ \\
\hline Chitra & 50 & $14 \%$ & $10 \%$ & $4 \%$ \\
\hline Sehgal & 50 & $8.17 \%$ & $4.17 \%$ & $4 \%$ \\
\hline Tiwari & 50 & $8 \%$ & $2 \%$ & $6 \%$ \\
\hline Present study & 50 & $8 \%$ & --- & $8 \%$ \\
\hline
\end{tabular}


The lowest incidence of aberrant left hepatic artery arising from left gastric artery was $6.1 \%$ reported by Iezzi [14] and the highest incidence was reported by Urugel $21 \%$ [17]. The incidence in the present study was $8 \%$.

\section{Embryological basis}

During fetal life, hepatic tissue is supplied by three embryonic hepatic arteries, namely, left hepatic, right hepatic and common hepatic arteries. There after regression occurs in relation to right and left hepatic arteries. Persistence of right and left hepatic arteries leads to the development of aberrant hepatic arteries [20-22].

For the normal development of any viscera there will be continuous synthesis of adequate quantities of signaling molecules and growth factors, which are produced by the mammalian cells. In case of any interference in the synthesis of signaling molecule and growth factor leads to development of visceral anomalies. In such cases if an artery fails to originate from the usual (normal) position being the only source of supply to the particular lobe, it is then called as replaced artery [23]. During gastrectomy and hiatal hernial repair surgical procedures the left hepatic artery arising from the left gastric artery frequently gets injured, hence the aberrant vessels must be kept in mind during surgical interventions. Having an accessory left hepatic artery contributes to the collateral arterial circulation in case of vascular occlusion in porta hepatis $[24,25]$.

In case of liver transplantation patients with the presence of accessory hepatic arteries calls for multiple vascular anastamosis to be done between donor and recipient vessels. If accessory vessels are not anastomosed properly it may lead to severe postoperative complications such as necrosis of liver parenchyma, acute liver failure and other fatal complications [26]. Studies have also shown that in presence of aberrant vessels can result in difficulty during catheter placement in case of chemoembolization and hepatic arterial infusion chemotherapy procedures [27]. Presence of aberrant hepatic arteries can prove to be fatal as there will be more chances of accidental ligation during surgeries done of liver tissue. Simultaneously presence of aberrant hepatic arteries can also lead to potential error in diagnosing angiographic procedures $[28,29]$. Hence it is advisable to subject the patient to thorough preoperative procedures to reduce the fatal complications during hepatobiliary surgeries.

\section{Conclusion}

Presence of aberrant hepatic arteries, either as accessory or replacing is a common anomaly and it proves to be crucial in case of hepatobiliary surgeries as it may pose a threat of potential bleeding during surgical procedures. Hence a surgeon should be well equipped with the knowledge of aberrant hepatic arteries as it is also important during hepatectomy, gastric resection and liver transplantation surgeries.

\section{References}

[1]. Haller VA. Icones anatomicae quibus praecipuae aliquae partes corporis humani delineatae proponunturet arteriarum potissimum historia continetur. Gottingen. 1756.

[2]. Adachi B. Das arterien system der Japaner, Verlag der Kaiserlich-Japanischen university. Kyoto. 1928; 26-46.

[3]. Michels NA. Blood supply and anatomy of upper abdominal organs with a descriptive atlas. Lippincot Co.1955; 26-27.

[4]. Jones RM, Harely KJ. The hepatic artery: A reminder of surgical anatomy. J R Coll Surgery Edinb. 2001; 46: 168-170.

[5]. Covey AM, Body LA, Maluccio MA, Getrajdman GI, Brown KT. Variant hepatic arterial anatomy revisited: Digital subtraction angiography performed in 600 patients. Radiology. 2002; 224: 542-47. PMID: 12147854.

[6]. Williams PL, Bannister LH, Berry MM, Collins P, Dyson M, Dussek JE, et al. Gray's anatomy (38 ${ }^{\text {th }}$ edtn), Churchill Livingstone. 2000; 1548-1552.

[7]. Bergman RA, Afifi AK, Miyauchi R, hepatic artery. Illustrated encyclopedia of human anatomic variations: opus II: Cardiovascular system: Abdomen: Variations in branches of Coeliac trunk.

[8]. Tiwari S, Roopashree R, Padmavathi G, Varalakshmi KL, Sangeeta M. Study of aberrant left hepatic artery from left gastric artery and its clinical importance. Int J Cur Res Rev. 2014; 6(17): 25-28.

[9]. Michels NA. Blood supply and anatomy of upper abdominal organs with a descriptive atlas. Philadelphia, Lippincot Co. 1955; 139-143.

[10]. Hazirolan T, Metin Y, Karaosmanoglu AD, Canyigit M, Turkbey B, Oguz BS, et al. Mesenteric arterial variaations detected at MDCT angiography of abdominal aorta. American Journal of Roentgenlogy. 2009; 192: 1097 1102 .

[11]. Hiatt JR, Gabbay J, Busuttil RW. Surgical anatomy of the hepatic arteries in 1000 cases. Ann Surg. 1994; 220: 50-52. PMID: 8024358.

[12]. Eaton PB. The Coeliac axis. Anat Rec 1917; 13: 369-74.

[13]. Andujar RL, Moya A, Montalva E, Berenguer M, Manuel De Juan, Fernando San Juan, et al. Lessons learnt from anatomic variants of the hepatic artery in 1081 transplanted livers. Liver transplantation. 2007; 13: 1401 1404. PMID: 17902125.

[14]. Iezzi R, Cotroneo AR, Giancristofero D, Santoro M, Stroto MI. Multidetector- row computed tomography angiographic imaging of the Coeliac trunk: anatomy and normal variants. SurgRadiol Anatomy. 2008; 30(4): 303-310. PMID: 26929461

[15]. Winston CB, Lee NA, Jarnagin WR, Teitcher J, Dematteo RP, Fong Y, et.al. $\mathrm{CT}$ angiography for delineation of Coeliac and superior mesenteric artery variants in patients undergoing hepatobiliary and pancreatic surgery. American Journal of Roentgenology. 2007; 189: w13-w19. PMID: 17579128.

[16]. Rawat RS. CTA in evaluation of vascular anatomy and prevelance of vascular variants in upper abdomen in cancer patients. Ind J RadiolImag. 2006; 16(4): 457-461.

[17]. Urugel MS, Battal B, Boziar U, Nural MS, Tasar M, Ors F, et al. Anatomical variations of hepatic arterial system, coeliac trunk and renal arteries: an analysis with multidetector CT angiography. The British Journal of radiology. 2010; 83: 661-667. PMID: 20551256.

[18]. Chitra R. Clinically relevant variations of the coeliac trunk. Singapore Med J. 2010; 51(3): 216-219.

[19]. Sehgal G, SrivastavaAK, Sharma PK, Kumar N, Singh R. Variations of extrahepatic segments of hepatic arteries: A multislice computed angiography study. International Journal of scientific and research publications. 2013; 3(2): 1-8.

[20]. Couinaud C. Surgical anatomy of the liver revisited: Embryology. Paris, Couinaud. 1989: 11-24.

[21]. Michels NA. Newer anatomy of liver and its variant blood supply and collateral circulation. Am J surg. 1966; 112: 337-347. PMID: 5917302.

[22]. Miyaki T. Patterns of arterial supply of human featl liver: the significance of the accessory hepatic artery. Acta Anat 1989; 136: 107-111. PMID: 2816258.

[23]. Kulesza RJ, Kalmey JK, Dudas B, Buck WR. Vascular anomalies in a case of situs invertus. Folia morphol. 2007; 60: 69-73. PMID: 17533597.

[24]. Okano S, Sawai K, Taniguchi H, Takahashi T. Aberrant left hepatic artery arising from left gastric artery and liver function after radical gastrectomy for gastric cancers. World journal of surgery. 1993; 17: 70-74. PMID: 8447143.

[25]. Abid B, Douard R, Chevallier JM, Delmas V. Left hepatic artery: Anatomical variaations and clinical implications. Morphologic. 2008; 92: 154-161. PMID: 19008142.

[26]. Sugavasi R, Manupati S, Bandi S, Indira B, Jetti R. Origin of accessory left hepatic artery from left gastric artery in a south indian cadaver, its clinical importance. Anatomy journal of Africa. 2012; 1: 10-12.

[27]. Chiang KH, Chang PY, Lee SK, Yes PS, Ling CM, Lee WH, et al. Angiographic evaluation of hepatic artery variations in 405 cases. Chin J Radiol. 2005; 30: 75-81.

[28]. Hollinshed WH. Anatomy for surgeons. The thorax, abdomen and pelvis. 1st edition. New York. Hoeber-Harper, 1956.

[29]. Saeed M, Rufal AA. Duplication of hepatic artery. Saudi J Gastroenterology. 2001; 7(3): 103-108. PMID: 19861777. 